\title{
Verbal Communication of a Person with a Chatbot as a Discursive Practice in the Era of Digitalization: a Pragmatic Aspect
}

\author{
Raisa Babaeva $^{1 *}$, Dmitrii Babaev² and Manfred Peters $^{3}$ \\ ${ }^{1}$ Ivanovo State University, Yermak St., 39, Ivanovo, 153025, Russian Federation \\ ${ }^{2}$ Ivanovo Branch of the Russian Presidential Academy of National Economy and Public \\ Administration, Posadsky per., 8, letter A1, Ivanovo, 153002, Russian Federation \\ ${ }^{3}$ University of Namur, German Department, Rue de Bruxelles, 61, 5000 Namur, Belgien
}

\begin{abstract}
Based on the analysis of users dialogues and chatbots presented on the websites of German commercial firms, the article describes the linguistic and pragmatic features of human interaction with «virtual assistants», specifies the characteristics of chatbots and the texts generated by them, characteristics that make interactions anthropomorphic, and the parameters are also determined that indicate the artificiality of the communication between the client and the chatbot. The interaction of the user and the program created on the basis of artificial intelligence is carried out using the language of «daily people communication», therefore, this communicative interaction is considered in the article as a separate discursive practice with its own characteristics. The article notes that so far, when studying the interaction of customers and chatbots, the main focus has been on technical, economic and social aspects, but not linguistic ones. The empirical study of user dialogues with "virtual assistants» presented in the work contains conclusions that are of interest for formulating recommendations to clients who turn to communication services in order to obtain information about any product or service, as well as to representatives of Internet commerce and IT developers, who are developing concepts for using chatbots in sales.
\end{abstract}

\section{Introduction}

In the context of global digitalization, the economic, political, social conditions for the existence of a modern person are changing, which is reflected in the language. This is manifested, on the one hand, in the emergence of new lexical units, and, on the other hand, in the expansion of the discursive space, in which new genres and discursive practices appear.

A modern person becomes involved in computer-mediated communication, where he has to master new rules of social interaction in a virtual environment and learn online communication not only with real people, but also with computer programs, which cannot

* Corresponding author: nitdaf@mail.ru 
always be identified as «virtual computer interlocutors», since they are disguised in anthropomorphic images and communicate with a person in a language familiar to him. Communication of a user with a computer using specialized languages (for example, various programming languages) sets the framework for the interaction of communicants a person and a computer, where the difference between human-computer interaction (HCI) and human-human interaction (HHI) is realized. The interaction of a person and a computer with the help of an ordinary «human» language is perceived quite differently, while the ambiguity of the situation is also created by the fact that a computer program very often «pretends» itself to be a real person.

An example of such situations is the interaction of customers with chatbots that actively «communicate» with real people on social networks, in online stores, while performing certain tasks «programmed» by their creators. Such chatbots are involved in the real economic and political life of the global world community. Currently, the chatbot market has emerged, they have turned into a commodity and are offered by their creators to firms and politicians to promote goods and ideas among the population. Analysts point out that the chatbot market will grow in the near future and will increase by $25 \%$ by 2025 . By the end of $2020,80 \%$ of customer requests will come from chatbots [1].

In this article, we will look at a number of issues related to the interaction of humans and chatbots in the field of online sales. By chatbot, we mean "computer programs designed to automate communication and the communication process, capable of maintaining a dialogue with a person using speech recognition technologies, or working according to pre-configured «question - answer» scenarios» [2].

Conversational chatbots are based on artificial intelligence technologies, they are known by several names, such as «natural language interfaces», «conversational user interfaces», «intelligent virtual assistants», etc. According to Srini Janarthanam, «conversational user interfaces provide the best of both worlds: human-like natural interaction combined with the advantages of digital technologies», they have proven themselves in various fields and in the near future chatbots «will not go anywhere», they are characterized by a long-term perspective [3].

\subsection{Problem Statement}

\subsubsection{Economic approach}

From an economic point of view, the use of chatbots when organizing commercial sales via the Internet has a number of advantages [4 - 8] over using a call center with «live» employees (some of the advantages remain in the case of using a data center with a minimum of «live» employees). These advantages include: 1) round-the-clock and yearround availability of a chatbot for clients with good hosting (a sales site is available for a client - this means a bot is available; there is an opportunity to communicate in a messenger - a bot is also available, etc.); 2) the ability to process mass (both typical and, in some cases, diverse) customer requests, with minimum client waiting time; 3) parallel collection of statistics, metrics, etc. when a bot is working, which dramatically increases the possibilities of personalizing sales for a specific client; 4) the ability to reconfigure and even adapt the bot for specific tasks, platforms, communication channels, ranging from simple instant messengers and phone calls to complex dialogues, which dramatically increases the possibilities of customers' reach (a client that is not available on one platform, in a messenger, etc., may be available on another platform, in another messenger); etc. capabilities; 5) and the most important advantage for commercial activity - significant savings on distribution costs in general, savings on staff wages and equipment depreciation, saving time for order processing, etc. In conclusion let us add that in this article we restrict 
ourselves to the analysis, if we can call them that, «bots for ensuring commercial sales», but in real life bots can be used for more «creative» and intelligent processes, up to the use of a chatbot as HR manager or Web-designer [9].

From an economic perspective, specially selected KPIs (Key Performance Indicators) can be used to assess the effectiveness and efficiency of using chatbots in commercial sales, which are traditionally focused on assessing the degree of achievement of goals and the possibility of optimizing processes. There are 3 main categories [10] of «quantitative» KPIs: metrics that reflect the implementation of the main tasks by the chatbot for which it was created (increase in sales for the period and by product groups and in assortment; expansion of the client base; increase in the frequency of communication with customers; increase in the number customer information; quantitative characteristics of brand promotion; decrease in hours and minutes in the average and total workload of call center employees, technical support, couriers, etc., and, ultimately, an increase in profit and/or profitability), metrics reflecting interaction of the bot with the user (the number of engaged, active, repeated and other categories of users; the number of dialogues in general and with a specific user in the context of time and problems; the number of messages in written dialogues, including read ones, the number of replicas in other dialogues) and metrics, showing the result of dialogues (here it is most difficult to quantify, it is preferable to trivial assessments; for example, you can indicate: the percentage of errors while processing requests; the percentage of dialogues that led to the achievement of the goals set for the bot; the percentage of dialogues that did not lead to the achievement of the goals set for the bot, divided by the groups of reasons; you can also relate the duration of the dialogues to their goals, etc.). The task of philological science from the applied commercial positions here will mainly be reduced to the search for «quality» KPIs, in the sense of KPIs that reflect the qualitative impact of chatbots on sales.

\subsubsection{Linguistic approach}

The linguistic aspects of the consideration of human communication with chatbots are much less often the object of special study compared to the huge amount of works that consider the economic, social and technical aspects of the functioning of chatbots. A detailed linguistic analysis of the interaction between the user and the chatbot is presented in the work of the German researcher N. Lotze, who, based on the study of various linguistic parameters of the user's dialogues with four German-speaking chatbots, offers a communication model, which indicates the main parameters of such interaction: the user's communicative actions are determined by cognitive factors, goals and linguistic competence, while the actions of the chatbot are mechanistic and determined by the data, scripts, and the goals of the dialogue embedded in the program [11].

Linguists are interested in such issues as determining the place of HCI in a number of discursive practices, identifying the characteristic features of the user's communicative behavior within the framework of this communication, anthropomorphic features in the communicative behavior of a chatbot, the possibilities of a virtual interlocutor in certain discursive conditions [11 - 13].

One of the prerequisites for describing the interaction of a user and a chatbot should be considered the concept of discursive practice, which we consider following O.S. Issers as an activity and social experience, given in direct observation and requiring clarification due to its accessibility for superficial observation [14].

Communication with chatbots is already the reality in which our contemporary is involved; this is a new discursive practice waiting to be understood and analyzed. 


\subsection{Research questions, purpose of the study, research methodes}

The article deals with situations of communication with German-speaking chatbots that interact with clients on the websites of German companies. The purpose of the analysis of the material is to identify the linguistic, pragmatic and discursive features of the "communicative behavior» of the chatbot in the field of commercial sales, in order to help the user to realize their intentions and achieve their goals through successful communication with the virtual assistant.

The material of the study was dialogues with chatbots presented on German-language websites of commercial organizations and educational institutions. (https://www.otto.de/clara/; https://www.magenta.at/; https://zukunftdermedizin.at/ и др.). The analysis was carried out within the framework of the discursive paradigm using the method of conversion analysis, the method of quantitative calculations, and the method of context analysis based on the concepts of pragmatics.

At the first stage of the study, based on the analysis of onyms, general characteristics of the chatbots of the German-speaking space, described on the website https://www.chatbots.org/language/german/, were given. At the second stage, the main communication strategies and language features of the texts generated by the chatbot were identified.

\section{Findings}

To achieve the success of speech interaction, the creators of dialogue systems give virtual agents anthropomorphic features and model speech behavior similar to the communicative behavior of people. At the same time, the lack of cognitive abilities in chatbots is a source of communication failures in interaction and indicates the artificiality of communication.

\subsection{Human-Chatbot interaction: antropomorphism}

Chatbots are given various images that should evoke certain associations and emotions in users. An analysis of the images of the described chatbots presented in the Germanspeaking sector of the Internet space on the website https://www.chatbots.org/language/german/ showed that chatbots focused on providing services are mostly anthropomorphic creatures, i.e. their images look like ordinary people (32). Another group is formed by humanoid chatbots (6) - they have images of cute robots or other fantastic creatures, for example, chatbot Tony, a football expert, looks like a little man with a soccer ball instead of the head ELIAS (Auskunfts- und Info-System auf der Website des Projektes ELSTER). The third group is formed by zoomorphic chatbots (2), for example, the chatbot of the organization Swäbisch Holl Bausparen appears to users in the form of a fox and named Sparbaufuchs.

Analysis of onyms used to give robots proper names revealed the following cases of nominations: 1) the use of one name, usually a short one - Noora, Julia, Jana, Clara, Nina, Janina, Lena, Sabine, Sophie, Ina, Lisa, 2) use of first and last name - Ann Bottler, Wigald Boning; Stefanie Fischer (Deutsche Bundeswehr), Christian Wagner (Deutsche Bundeswehr); 3) use of a surname with an indication of professional affiliation and academicity - Dr. Stein, Dr. Electric; 4) artificial names, which are often acronyms or composites - SLUB (Staatsuniversität Bibliotek Dresden), ASKademikus (Universität Dresden); 5) artificially created «speaking» names - Neunmalklug (the creators probably wanted to emphasize that the bot is very smart).

The study of the gender aspect of the nomination of chatbots made it possible to reveal a pattern that the majority of anthropomorphic bots involved in services and sales are 
feminitive - Sina (Sparkasse Gelsenkirche), Marie (ebay), Clara (Otto) and others; masculine bots are much less common - Wigold Boning (Epson Store Deutschland), Dr. Stein (natursteinpflege24), Albot (USB Köln). This is probably due to the fact that in the real life of the German-speaking society women are mostly employed in the service sector; masculine chatbots are associated, as a rule, with those spheres where men are more represented.

In dialogues, anthropomorphism is manifested in the fact that texts generated by the chatbot contain emotional components - interjections, modal words. For example, the virtual assistant of the Heidi educational services website, when asked if the interlocutor needs information about studying in a bachelor's degree, reacts very emotionally, using the interjection: Huuui, hierzu können wir dir ganz viel erzählen! The chatbot also responds very expressively to the question about the amount: "Ach was!», Alles! The next chatbot response question uses the modal particle denn, which confuses the statement: Wonach suchst du denn? There are even phraseological units in the bot's responses: Was kostet der Spa/Besuch? - Ich verstehe nur Bahnhof. Passe deine Wortwahl an.

The virtual assistant «tries» to build a dialogue according to the «dialogue-sales model» in a real store: a greeting, a question about desires, a budget, an offer-recommendation, a farewell and gratitude for a visit: Hast du ein bestimmtes Budget? Wonach suchst du denn? Zusammen können wir dein neuestes Lieblingsstück finden. Starte einfach die Suche, indem du auf den Button klickst oder tippe einfach ein, was du suchst. Bis bald, hoffentlich!

Some bots can respond to questions that go beyond the sale and purchase, for example, Clara (Firma Otto) bot, when asked how things are, answers the way it could in real life: Wie geht es dir, Clara? - Danke der Nachfrage. Mir geht es prima. Ich hoffe, es geht Dir auch gut. And other answers of this virtual assistant can be considered successful: - Warum streiten die Deutschen in der Pandemie? - Ein ordentlicher Streit kann manchmal sehr wichtig sein. - Clara, was meinst du über Angela Merkel? - Bisher habe ich noch nicht mit Bundeskanzlerin Angela Merkel plaudern können.

Imitation of real communication is also created by personalization, which manifests itself in a large number of uses of personal and possessive pronouns, as well as the observance of the norms of politeness, which is embodied in the use of the corresponding words.

\subsection{Human-Chatbot interaction: artificiality, suggestiveness}

The artificiality of communication within the framework of the dialogue with the chatbot is manifested in the inappropriateness of some responsive responses, as well as in failures caused by incorrect spelling, which could be easily resolved in a dialogue with a real assistant. For example, Nora bot, instead of recommending a spa, cannot understand what it is about, because the spelling of the city name did not match the literary version of the German language: - In welcher Region oder Stadt suchst du ein Spa? - Sankt-Gallen. - Ich verstehe dich nicht. Ich spreche nur Hochdeutsch und meine Aufgabe ist es ein Spa für dich zu finden. - Sankt Gallen. - Ich habe keine Ahnung, was du mir sagen willst $\Theta$. Bitte wiederhole dich mit anderen Worten. After the correct spelling of the name of the city - St. Gallen - the virtual assistant immediately suggested different SPA options.

Sales virtual assistants can «chat» on abstract topics, but they always return to their main product or service: - Hallo, Nora! - Hei!Ich kenne mich in der Spa-Welt super aus. Was für ein Spa suchst du? - Wie geht es dir, Nora? - Viel zu tun (2), aber morgen gehe ich ins Spa, dann kann ich wieder so richtig ausschalten! (:.). - Was machst du jetzt? - Ich überlege mir gerade, welches Spa ich dir empfehlen könnte.

The difference from a dialogue with a real seller is also manifested in the fact that the bot cannot give an answer to clarifying questions if it is not contained in its «memory». For 
example, when recommending a spa salon, the bot cannot answer the question whether there are restrictions related to the coronavirus: - Gibt es Einschränkungen wegen Coronavirus? - Nach folgenden Kriterien kann ich für dich Spas suchen:...

The generated text of the bot, as a rule, is larger in terms of the volume of the user, which is not entirely natural in the dialogue. For example, Clara (Otto) bot generates a long text when asked about the weather: Wie findest du das Wetter heute? - Warum willst du wissen, wie ich das Wetter heute finde? Ich wollte gerade über etwas Anderes sprechen und zwar: Da habe ich einen Tipp für dich: Melde dich für den OTTO-Newsletter an. So bekommst du alle News zu exklusiven Aktionen, Produktneuheiten, Top-Schnäppchen, Gutscheinen, Gewinnspielen, aktuellen Trends oder praktischen Serviceleistungen - und das immer als Erster. Hier geht's zur Anmeldung!

Chatbots' replicas are characterized by repetition of standard phrases (DefoultAntworten), which allow you to correct the situation when there is no answer to the question: - Ich habe keine Ahnung, was du mir sagen willst $\Theta$. Bitte wiederhole dich mit anderen Worten.; - Sorry, ich verstehe dich nicht. Einfache Sätze verstehe ich am besten. Ich bin stets bemüht deine Sätze zu verstehen. Bei kurzen und einfachen Sätzen fällt mir das am leichtesten.

\section{Conclusions}

In the course of the study, it was concluded that when communicating with a chatbot in the field of sales, the user should take into account the capabilities of the virtual assistant and build his statements and questions, without being distracted from the topic, the requests should be small in volume, real and clearly formulated. These characteristics correspond to Grice's postulates [15] (maxims of quantity, quality, attitude, method), following which will lead to a harmonious dialogue and the realization of the client's intentions. The important role of these postulates in this discursive practice is explained by the limited capabilities of the «intelligent automated interlocutor». Compliance with the norms of politeness in the discursive practice of communication between the «human client» and the chatbot introduces elements of play and entertainment into communication. The results obtained can be useful for formulating recommendations to clients who turn to communication services in order to obtain information or any service, as well as trade business (primarily representatives of Internet commerce) and IT developers who are engaged in the development of concepts for using chatbots and dialogs in which chatbots participate.

It seems promising to study the principles of communication between a «human client» and a chatbot on the basis of different languages in order to find out whether cultural and national characteristics are taken into account when creating chatbots.

\section{Acknowledgments}

This paper was financially supported by the Russian Foundation for Basic Research, grant No. 20-012-22046.

\section{References}

1. N. Graber, Deshalb sind Chatbots die Zukunft des Marketings, April 14, 2020 (2020).URL: https://www.microsoft.com/de-de/microsoft-365/business-insightsideas/resources/how-chatbots-are-the-future-of-marketing. 
2. L. E. Malygina, Chat-boty i iskusstvennyj intellekt: perspektivy razvitiya televizionnogo promodiskursa, Aktual'nye problemy filologii i pedagogicheskoj lingvistiki, 4 (32) (2018). URL: https://cyberleninka.ru/article/n/chat-boty-iiskusstvennyy-intellekt-perspektivy-razvitiya-televizionnogo-promodiskursa. URL: https://cyberleninka.ru/article/n/chat-boty-i-iskusstvennyy-intellekt-perspektivyrazvitiya-televizionnogo-promodiskursa.

3. S. Janarthanam, Hands-On Chatbots and Conversational UI Development: Build chatbots and voice user interfaces with Chatfuel, Dialogflow, Microsoft Bot Framework, Twilio, and Alexa Skills (Kindle Edition, 2018)

4. V. A. SHovin, Programma shatbot - chat-bot ili virtual'nyj sobesednik, Matematicheskie struktury i modelirovanie, 4, pp. 96-101 (2016).

5. N. S. Konstantinova, A. V. Degteva, Dialogi $i$ chat-boty in Prikladnaya i komp'yuternaya lingvistika. Kollektivnaya monografiya (Lenand, 2017)

6. D. A. Novikov, E. M. Spiridonova, CHat-boty kak instrument internet-biznesa in Zametki po informatike i matematike. Sbornik nauchnyh statej, Vypusk 9 (YArGU, 2017)

7. SH. Aliev, CHat-bot - prilozhenie, drug, marketingovyj hod?, Internet-nauka, 12, Pp. 48-54 (2016)

8. M. M. Lachugina, U. S. Opaleva, Osnovy Internet-reklamy (GUAP, 2019)

9. A. Saprykina, CHat-boty obreli vtoroe dyhanie?, ComNews.ru, Elektronnoe SMI. 25 May 2020, (2020). URL: https://www.comnews.ru/content/207271/2020-05-25/2020w22/chat-boty-obreli-vtoroe-dykhanie.

10. A. Zubkova, KPI dlya robota. Kak izmerit' effektivnost' chat-botov, Sostav nezavisimyj proekt brendingovogo agentstva Depot WPF, 22 May2018 (2020).URL: https://news.rambler.ru/internet/39910326/?utm_content=news_media\&utm_medium= read_more\&utm_source=copylink).

11. N. Lotze, Chatbots. Eine linguistische Analyse, Sprache - Medien - Innovation, 9 (2016)

12. L.E. Malygina, «Virtual'nye sobesedniki»: perspektivy razvitiya televizionnogo promodiskursa, Verhnevolzhskij filologicheskij vestnik, 4 (2018). URL: https://cyberleninka.ru/article/n/virtualnye-sobesedniki-perspektivy-razvitiyatelevizionnogo-promodiskursa.

13. G. P. Hug, Talk with the Bots Gesprächsroboter und Social Bots im Diskurs (Universität Innsbruck, 2018)

14. O. S. Issers, Diskursivnaya praktika kak nablyudaemaya real'nost', Vestnik OmGU, 4 (2011). URL: https://cyberleninka.ru/article/n/diskursivnaya-praktika-kaknablyudaemaya-realnost.

15. G. P. Grajs, Logika i rechevoe obshchenie in Novoe v zarubezhnoj lingvistike. Vyp. 16. Lingvisticheskaya pragmatika (Progress, 1985) 